\title{
Business and Peace
}

\author{
Lessons from Bougainville*
}

\author{
Kylie McKenna \\ Australian National University
}

\footnotetext{
Peacebuilding

Business

Natural resources

Resource conflict

Bougainville
}

This paper discusses the relevance and utility of the existing literature on business and peace for resolving armed conflicts related to natural resources. The paper argues that this scholarship is valuable in so far as it opens debate on the potential positive contributions of extractive companies to peacebuilding processes. However this scholarship primarily looks at areas affected by conflict to consider ways that companies with no previous connection to the area might establish a productive business. What is missing in this analysis is a critical engagement with the fact that resource companies are often heavily implicated in the causes of conflict, not just affected by the consequences. Drawing on a case study of Bougainville (Papua New Guinea), the paper highlights numerous roles for business in peacebuilding not previously identified in the business and peace literature. These contributions include very precise expectations for a company that was deeply entangled in the Bougainville conflict, yet wants to return to the island to resume mining. This finding has important implications for future research. In order to ensure the relevance of this scholarship to the extractive sector, there is a need to identify peacebuilding roles for an industry whose activities are often a key factor in the escalation of violence.
Kylie McKenna is a Research Fellow within the State, Society and Governance in Melanesia Program at the Australian National University. She completed her

$\mathrm{PhD}$ on Corporate Social Responsibility and resource conflict in Bougainville and Papua in 20I2. Dr McKenna's research explores the dynamic nexus of business, conflict, violence and peacebuilding. Her case study foci over the past five years has been the Panguna mine (Bougainville), the Grasberg mine (Papua) and the Tangguh Liquefied Natural Gas project (West Papua).

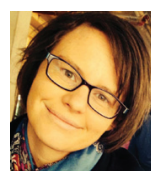

State, Society and Governance in Melanesia, School of International, Political and Strategic Studies, The Australian National University, Canberra ACT O200, Australia

Kylie.mckenna@anu.edu.au

* I am grateful to Anthony Regan, John Braithwaite, Martina Wardell and reviewers for their insightful comments, suggestions and corrections on earlier drafts of this paper. All remaining errors are my own. 
HE UNITED NATIONS ESTIMATES THAT at least $40 \%$ of internal conflicts globally are related to natural resources (UNEP, 2009, p.30). Given the correlation between natural resources and armed conflict, there is an urgent need to find more peaceful avenues for the extraction of natural resources. This paper questions the relevance and utility of existing scholarship on business and peace for resolving armed conflicts related to natural resources. The paper argues that this scholarship is valuable in so far as it opens debate on the potential positive contributions of extractive companies to peacebuilding ${ }^{7}$ processes. However this scholarship primarily looks at areas affected by conflict to consider ways that companies with no previous connection to the area might establish a productive business. What is missing in this analysis is a critical engagement with the fact that resource companies are often heavily implicated in the causes of conflict, not just affected by the consequences. One consequence of this focus is that it predominantly highlights the indirect positive effects of economic development, rather than identifying proactive strategies for corporations. The paper argues that the lack of attention to cases where business has been a factor in prior conflict not only limits its practicality to resolving resource conflict, it also weakens pressure on the extractive sector to take a more hands-on role in peacebuilding.

Drawing on a case study of Bougainville (Papua New Guinea (PNG)), the paper highlights numerous roles for business in peacebuilding not previously identified in the business and peace literature. It does this by juxtaposing the recommendations of the business and peace literature with the expectations expressed by locals in one resource-related conflict. The Bougainville case represents a unique opportunity to explore the relevance of the business and peace scholarship. This is because negotiations are currently unfolding on the island regarding the potential reopening of the Bougainville copper mine which ceased operations in 1989 due to violence.

The paper draws on interviews conducted as part of a larger comparative study on corporate social responsibility (CSR) and resource conflict in Bougainville and Papua ${ }^{2,3}$ (McKenna, 20I2). In total, $37^{4}$ interviews for the Bougainville case were conducted in 2010 in five main areas: Buka (the administrative centre of Bougainville), Arawa (the old mining town of the Bougainville copper mine), Panguna (the site of the Bougainville copper mine), Port Moresby and Canberra

1 This paper draws on a broad definition of 'peacebuilding' as the creation of a 'structure of peace based on justice, equity and cooperation' (Gawerc, 2006, p.49). The term itself has a relatively short history, only becoming popularised in 1992 following Boutros BoutrosGhali's document, An agenda for peace, preventive diplomacy, peacemaking and peace-keeping. Boutros-Ghali originally defined peacebuilding as applicable only to 'post-conflict' situations with a particular emphasis on projects that bring States involved in international conflict together (Boutros-Ghali, I992).

2 This research was funded by World Vision Australia.

3 The study was undertaken over a 3.5 year period for a doctoral thesis.

4 In two cases there was more than one interviewee present for one interview, so the total number of interviewees for the Bougainville case was 39 . 
(the capitals of PNG and Australia). Participants included corporate executives, former mine employees, landowners, women's and religious leaders, as well as ex-combatants ${ }^{5}$. Interviews focused on the participants' experiences of current and past corporate community programmes and their relevance to resolving resource conflict.

The paper begins with a brief review of the literature on business and peace $^{6}$. This is followed by an introduction to the Bougainville conflict. It then discusses how and why a debate is under way on Bougainville about resuming large -scale mining despite the centrality of the Bougainville copper mine to the decade-long civil war. The paper concludes by outlining the positive roles for business in peacebuilding that are omitted in the business and peace literature. The aim is not to dismiss the important groundwork of existing business and peace scholarship. Rather its goal is to identify avenues through which it can be extended through a focus on the roles of corporations in peacebuilding where their activities have been a source of conflict.

\section{Business, conflict and peacebuilding}

Since the end of the Cold War there has been a perceived general shift in the global dynamics of armed conflict. This shift is characterised by the prominence of intra-state conflict rather than inter-state wars (Kaldor, 2007). A key feature of these 'new wars' is the exploitation of natural resources as either a key source of internal conflict, or their use by rebel movements to finance the start-up costs of civil war (Ross, 2004, p.40). The roles of natural resources have generated interest in defining the responsibilities of corporations operating in zones of conflict. Numerous organisations have been working hard to delineate these responsibilities through 'soft regulation', such as the Voluntary Principles on Security and Human Rights and the UN Global Compact policy dialogue on the Role of the Private Sector in Zones of Conflict (20IO). In tandem with these initiatives, a new area of scholarship on the 'untapped potential' of the private sector in peacebuilding has emerged (Andersson, Evers, Sjostedt, 20II; Bais \& Huijser, 2005; Ford \& McKenna, 2008; Fort \& Schipani, 2004; Fort, 2007; Gerson, 200I; Oetzel, Westermann-Behaylo, Koerber, Fort \& Rivera, 20I0; Rettberg, 2007; Santa Barbara, Dubee \& Galtung, 2009; Shankleman, 2006; Sherman, 200I \& 2002; Wenger \& Mokli, 2003; Zandvliet, 2005). There

5 Sources of data for the Bougainville case include: Rio Tinto executive-Australia: I, BCL executive: 2, former mine employee: 8, Autonomous Bougainville Government (ABG) Chief Executive Officer: 3, civil servant: 3, resident/landowner from a mining lease area: 5, landowner group chairman: 2, women's leader: 5, Me'ekamui Government member: I, small scale miner: 2, ABG adviser: 4, peace maker: I, ex-combatant: 2 .

6 For a comprehensive review of the business and peace literature, see: Oetzel, Westermann-Behaylo, Koerber, Fort \& Rivera, 20Iо. 
is also a budding scholarship on natural resources and peace processes. However, this literature is dominated by a focus on the relationship between states and opposition movements, with the role of business actors on the periphery of the analysis. The predominant focus is on income-sharing frameworks and power-sharing arrangements, both of which are important in the Bougainville case but beyond the scope of this paper.

The existing business and peace literature identifies five main avenues through which business can nurture peace: I) fostering economic development; 2) adopting principles of external evaluation; 3 ) contributing to a sense of community; 4) engaging in track-two diplomacy; and 5) engaging in conflict-sensitive practices/risk assessment (Oetzel, Westermann-Behaylo, Koerber, Fort \& Rivera, 20IO, p.355). These activities can be further distinguished according to the level of action required by corporations: I) the private sector can play indirect roles in peacebuilding through 'business as usual'; and 2) corporations can play a proactive role in 'peacebuilding'.

Regarding the indirect actions that corporations can take to promote peace, Fort and Schipani (2004, p.II) argue that corporations are engines that produce jobs, and with them the economic and social benefits that follow from employed individuals. Similarly, Gerson (200I, p.I03) argues that business has an important role to play in peacebuilding as 'conflict settlement requires the injection of hope born of employment and economic opportunity' and 'only the private sector can provide this over the long term'. The logic is that jobs and economic opportunity offer new incentives to maintain stability and break the cycle of violence (Gerson, 200I, p.I09).

A further example of peace promotion via economic development is evident in Gerson's (200I, p.I07) claim that the characteristics of business logic can be useful in conflict management processes. Business can provide 'managerial know-how and expertise to enable all the actors in the field-the World Bank, the UN, and civil society-to operate in a more streamlined and synergistic fashion' (Gerson, 200I, p.I07). This view is shared by Wenger and Mockli (2003, p.8) who argue that corporations 'can transfer know-how with regard to private sector development especially to local communities' (2003, p.8). The emphasis here, as with benefits associated with economic development, is that business can have 'positive economic spill overs' (Oetzel, Westermann-Behaylo, Koerber, Fort \& Rivera, 20Io, p.355) to the promotion of peace. In other words, corporations are not asked to amend their business practices to adopt specific 'peacebuilding roles'. Rather, they are asked to conduct their usual business activities with the added requirement that they adhere to standard business ethics in the hope that this will have 'trickle down' effects on peacebuilding.

Indeed, a key contributor to the business and peace literature, Timothy Fort, argues that business contributions to sustainable peace do 'not require a wholesale transformation of corporate governance. [However] it does require a stronger focus on commonly accepted understandings of ethical business practices' (Fort, 2007, p.5). Examples include the adoption of international codes of conduct regarding labour practices and environmental standards, as well as broader commitments to anti-corruption and transparency (Oetzel, 
Westermann-Behaylo, Koerber, Fort \& Rivera, 20I0, p.364). While there are some doubts as to the utility of 'soft regulation' in the absence of an international monitoring mechanism (Oetzel, Westermann-Behaylo, Koerber, Fort \& Rivera, 2010, p.365), Fort (2007, p.133-34) argues that they overlap with the promotion of peace by way of offering checks and balances to corporate power.

Strategies that emphasise the indirect ways that business can foster peace are primarily pragmatic and have been shown to appeal to business. A report published by the Collaborative Engagement Project (2003) for example, analyses the potential role for corporations in peacebuilding from the corporate perspective. The report suggests that corporations do consider peacebuilding a part of their CSR, but are unlikely to call it 'peacebuilding' as this is viewed as too political a term. Further, there is a belief that corporations do not have the expertise or capacity to adopt a proactive peacebuilding role. A similar finding also emerged in interviews conducted by the author of this paper. Corporate executives stated that they do not see a role for corporations in the promotion of peacebuilding. However, there may be opportunities for peacebuilding activities to occur through existing CSR frameworks, as opposed to the generation of new policies and programmes under the label 'peacebuilding'. This indicates that the potential roles for business in peacebuilding processes are not only largely indirect, but also voluntary.

In terms of direct or proactive roles for the private sector in peacebuilding, the literature suggests a broad continuum of business responses to conflict which 'may be more or less appropriate' (Oetzel, Westermann-Behaylo, Koerber, Fort \& Rivera, 20I0, p.353). 'For instance, attempts to reduce the conflict are not appropriate for track-two actors, such as firms in the private sector, at the height of a conflict when there is an outbreak of violence' (Oetzel, Westermann-Behaylo, Koerber, Fort \& Rivera, 20I0, p.353). Firms should therefore wait for some sort of ceasefire until they can play a mediating role, contribute to economic development or contribute to a sense of community (through for example, employing ex-combatants from different sides of the conflict). While it is important to recognise the stages of conflict and the appropriateness of third-party involvement, it is equally important to move beyond this to consider the role played by particular companies in the eruption of conflict in the first place. Questions to be considered include: was there, for example, a window of opportunity in which the corporation could have engaged in 'conflict prevention' through track-two diplomacy? Could the company have negotiated a pause in production in order to leverage negotiations between conflicting parties? ${ }^{7}$ Did the company's activities generate or contribute to the 'causes' of the conflict? Did its responses to the emergence of conflict contribute to its escalation? Did conflict escalate due to a fatality in the vicinity of an extractive project orchestrated by company or

7 For a comprehensive review of the business and peace literature, see: Oetzel, Westermann-Behaylo, Koerber, Fort \& Rivera, 2010. 
state security? ${ }^{8}$ The point here is that any proactive measures put forward for business in peacebuilding must also recognise that those same corporations may be deeply enmeshed in the dynamics of the conflict. Even though this is likely to significantly alter the appropriateness of current corporate engagement in peacebuilding processes, recognition of this dynamic is under examined in the business and peace literature.

The argument of this paper is that when companies critically and honestly engage with the ways in which their work may aggravate sources of conflict in particular locations, they may also find themselves in a better position to implement strategies to counter these dynamics (Banfield, Haufler \& Lilly, 2005). This may open new possibilities for corporations to play a 'redemptive' role in peacebuilding where its presence has been a factor in prior violent conflict., 90 This could occur, for example, through companies acknowledging their role in colonisation and decolonisation processes, or lobbying governments to rewrite exploitative or exclusionary contracts. Thus, while corporations are rightly argued to have the influence to leverage negotiations between conflicting parties, they may need to re-establish a social licence to operate before they can meaningfully take on these kinds of roles.

This is why it is important to incorporate more specific cases into the business and peace literature. Broad recommendations are important in generating normative arguments in favour of business contributions to peace. But we need to review these recommendations in context in order to consider their practicality and scope. Further nuance could be added to the business and peace literature through greater attention to detail in regards to the entanglement of business with particular situations of conflict. For example, Boege and Franks (20II, p.4) usefully distinguish two post-conflict scenarios which mining companies might operate within:

- Post-conflict development of new mines or reopening of old mines where mining was a factor in prior violent conflict

- Post-conflict development of new mines where mining was not a cause of the violent conflict, or where there was no pre-conflict mining

Distinctions such as those set out above make it easier to develop appropriate corporate strategies according to their operational scenarios. For instance,

8 It is beyond the scope of this paper to focus on all of these questions in detail. To do so would require a substantive analysis of evidence for and against allegations of BCL's complicity in war crimes. The focus of this paper is on what actions might be expected of a company in order to return to a post-conflict society both formally and informally, rather than on the specifics of the conflict itself which has received significant attention elsewhere. See for example: Filer (1990); Howley (2002); Regan (I998; 2010); Sirivi \& Havini (2004).

9 I am grateful to a reviewer of previous work for raising this idea.

10 President of the Autonomous Bougainville Government, John Momis, has also talked of BCL and Australia having the opportunity to redeem themselves for their roles in the Bougainville conflict (Laukai, 20I3). 
in cases where mining has not been a factor in prior violent conflict, it might be possible for corporations to foster stability through performing their core business activities (Bais \& Huijser, 2005, p.I24), such as the creation of new employment opportunities. However in cases where mining has factored in prior violent conflict, the same 'opportunities' may actually prolong or ignite conflict, depending on how they are pursued, and the historical context in which they are deployed. The point here is that in drawing on cases where business activity was a factor in prior conflict opens additional, and in some cases more transformative, opportunities for business engagement in peacebuilding than is currently suggested in the literature.

While this paper draws on an analysis of only one resource conflict, the argument is relevant for other corporations seeking to enter or return to postconflict societies where natural resources have been a source of conflict (e.g. the reopening of the Gold Ridge Mine in the Solomon Islands and the reopening of mines in Liberia). It also offers a number of restorative measures a corporation might adopt in situations where conflict has not yet ended and has led to the temporary suspension of a major resource facility ${ }^{11}$. More broadly, the paper contributes to existing cases of corporate engagement with historical injustice such as the investigation of the role of business in the South African Truth and Reconciliation Commission on apartheid (Nattrass, I999) and Rio Tinto's I996 apology for failing to act when the Queensland Government 'forcibly removed Aboriginal people from the Mapoon Mission on western Cape York and burnt their property' (Howitt, 200I, p.263).

To explore these issues in context, the paper now turns to a discussion of the possibilities for business to foster peace in Bougainville through negotiations on the resumption of large-scale mining. The story begins with an introduction to resource conflict in Bougainville. In contrast to the positive aspects of development in the business and peace literature, the Bougainville case highlights the negative spillover effects of extractive industries. Nonetheless, the case study provides insight into the corporate actions sought by locals in return for a new social licence to operate.

\section{Resource conflict in Bougainville}

The Autonomous Region of Bougainville is located in the south-west Pacific. The region comprises two main islands, Buka and Bougainville, and numerous surrounding smaller islands (see Fig. I). After the French explorer Louis de Bougainville sailed through the region in I768, Bougainville experienced several phases of colonial administration. Bougainville is geographically, racially and culturally linked to the Solomon Islands group (Dorney, 2000, p.38), but

11 Through, for example, attacks on energy infrastructure by non-state actors (Giroux, Burgherr \& Melkunaite, 2013). 
was controversially integrated into PNG. Scholars estimate human occupation on Bougainville at almost 30,000 years (Griffin \& Regan, 2005, p.xxvii). However despite this long history, the population remains relatively small at approximately 300,000 .

Prior to the 2oth century Bougainvilleans did not share a strong sense of unified identity. Rather, people identified themselves according to small independent groups marked by distinct languages and customs. In the latter half of the Igoos the Australian and PNG governments became increasingly interested in developing the natural resources located on Bougainville. This meant that any suggestion that Bougainville might break away from PNG were resisted. By this time, a nascent 'Bougainvillean' identity had already emerged, the chief marker of which was the dark skin colour of Bougainvilleans in contrast to the peoples of PNG (Nash \& Ogan, I99०, p.9).

Figure 1 Map of Bougainville

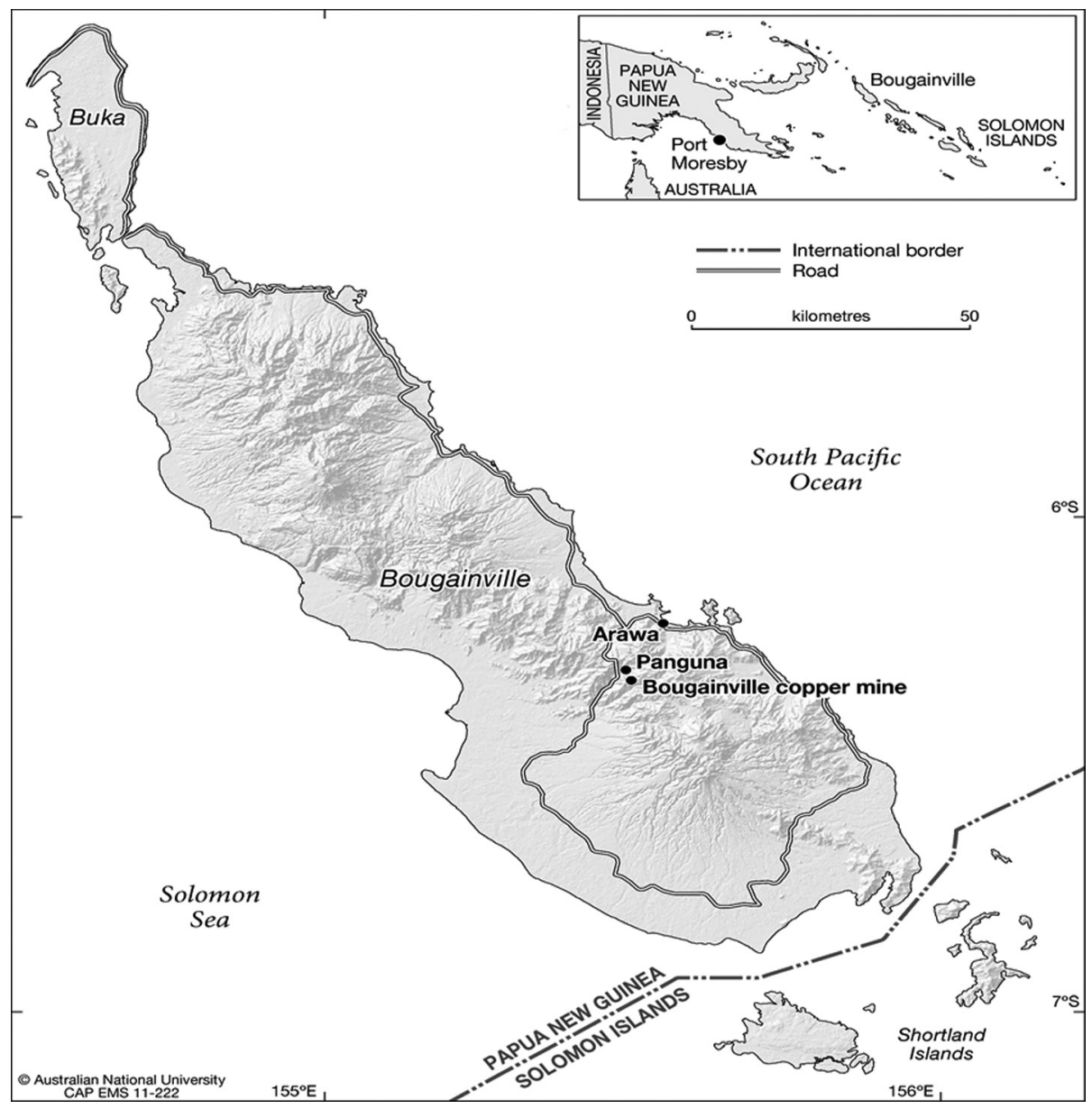


Rich deposits of copper ore were discovered at Panguna, central Bougainville, in I964. This led to the Australian Administration's eviction of local landowners to commence the development of what became the Bougainville copper mine (Sirivi \& Havini, 2004, p.xviii). At this point the Australian Government was planning for the decolonisation of PNG. The discovery of natural resources on Bougainville represented a valuable source of income through which this project might be financed, laying an economic foundation for an independent PNG. The development of the mine in concert with arrangements for the decolonisation of PNG and the secessionist aspirations gaining momentum on Bougainville, laid the early conditions for conflict. The result was a decadelong civil war, which claimed the lives of between I000 and 2000 people through direct fighting, but many more through the indirect effects of the war (Braithwaite, Charlesworth, Reddy \& Dunn, 20I0, p.87).

\section{Bougainville Copper Limited enters the conflict}

Bougainville Copper Limited (BCL) became deeply caught up in the processes leading to Bougainville's political incorporation into PNG. This was due to the timing of BCL's entry, the Australian origin of the firm and the fact that it entered into a legal agreement with the Australian Government via the Territory of New Guinea, rather than with indigenous landowners. As a result, many Bougainvilleans perceived BCL as symbolic of Australian colonialism, and more specifically, as the providers of the financial capacity that cemented their entrapment in an unwanted political relationship with PNG.

BCL, a subsidiary of Cozinc Rio Tinto Australia (CRA), entered Bougainville in 1964, following geological confirmation of copper mineralisation in the Panguna/Kupei area (BCL, 20IO-II). CRA held the majority ownership with 53\%; 28\% was floated on the Australian Stock Exchange and I9\% was bought by the Australian Government for the future independent State of PNG (Dorney, $2000, \mathrm{p} .42)$. A large number of shares were also reserved for purchase by Bougainvilleans; however it is unclear how many actually benefited (Braithwaite, Charlesworth, Reddy \& Dunn, 20IO, p.I2).

The first major agreement between BCL and the Territory of New Guinea was reached and enacted by the Territory's House of Assembly in I967 (Denoon, 2000 , p.I). The 1967 Agreement committed the Australian Government and BCL to 'terms concerning taxation, royalties, environmental management, employment and infrastructure' (Denoon, 2000, p.3). Australian civil servants and lawyers for CRA negotiated the agreement without the consultation of local Bougainvillean landowners (Ogan, 2004, p.5). The lack of Bougainvillean involvement in the ${ }_{19} 67$ Agreement was reflected in the profit shares of the minerals produced, with only $5 \%$ of the government's royalty of $1.25 \%$ to be distributed among landowners (Ogan, 2004, p.5). 
Denoon (2000, p.3) argues that Australia's direction of the I967 Agreement indicates that it, rather than BCL, was responsible for the events that unfolded on Bougainville. A former CEO of BCL, Paul Quodling claims that the Administration was facing an enormous dilemma, 'whether to mine (accepting the attendant conflict with cultural standards) or not to mine (accepting the loss of economic benefit to independent PNG' (Quodling, I99I, p.I). How much weight this dilemma actually held in the Australian Government's decisionmaking process is open to speculation. However the eventual decision to pursue mining operations in the way that they did, suggests that, for the Australian Government, building an economic foundation to facilitate formal withdrawal from PNG, took precedence over any concerns about Bougainvillean customary land rights.

The land on which the copper mine in Bougainville was constructed belongs to small clan-based groups from the Nasioi ${ }^{12}$ language group, many of whom were forced to relocate (Ogan, 2004). 'When villagers refused to sell, the government expropriated their land and flew in riot police to clear the way for surveyors' (Denoon, 2000, p.3). According to a former BCL Chairman, Don Vernon, the company's management also had difficulties understanding the complexities of Nasioi land ownership. In particular, it was not 'immediately obvious that the Nasioi derived rights to land through matrilineal inheritance, especially as these rights appeared to be exercised by men'13 (Vernon, 2005, p.260).

The key issue regarding land ownership, however, was not that BCL failed to understand the complexities of customary land tenure but that the state possessed the power to override these systems and take control of natural resources. Because the state wielded the power to control Bougainville's natural resources, and the capacity to legislate, BCL primarily negotiated the terms of access to land with the Australian Government, rather than the individual or group of landowners. This arrangement bypassed the traditional Bougainvillean land tenure system, which made no distinction between surface and sub-surface rights, or allowance for those who did not share a cultural relationship to a tract of land to draw benefits from it. In this way, Bougainvilleans came to perceive BCL as entering into a legal agreement with an institution that did not have the legitimacy to control the land.

The sense of injustice felt by Bougainvilleans about the Australian/PNG decision-making power over their land was exacerbated by the inequitable distribution of mining revenue in favour of PNG over Bougainville ${ }^{14}$. While BCL made compensation payments to Bougainvilleans during the exploration phase of the mine's development, these were quite small, and a coherent plan

12 While the mine pit and many of its associated facilities were located on land owned by the Nasioi language group, other mine-related leases were on land belonging to other language groups.

13 For a description of the land demarcation process and the misunderstandings it created, see: Regan (2007, p.95-6).

14 For an analysis of rates of compensation at Panguna in contrast to later mines in PNG, see: Filer, Henton \& Jackson (2000, p.87-I00). 
to safeguard the economic rights of locals was absent from the I967 Agreement. In an attempt to address this inequity, a Bougainville leader, Paul Lapun, lobbied the Australian Administration to give landowners 5\% of the 1.25\% royalties it received from the mine plus an occupation fee of AU\$6.50 per acre of land (AU\$I6.25 per hectare) (Quodling, I99I, p.48). This did not add up to a significant sum for landowners, little more than 6 cents per AU\$Ioo of the value of minerals taken from their land (Ogan, 2004, p.5).

Lapun was criticised by some landowners who believed his advocacy resulted in a poor compensation deal for Bougainvilleans. Other Bougainvilleans, who were against the development of the mine altogether, questioned Lapun's mandate to negotiate the agreement at all. For some of these people, no amount of money would have been considered sufficient to agree to mining. The ig67 Agreement signalled to many Bougainvillean landowners that they would be required to suffer the social and environmental costs of a mining project to fund the development of a PNG nation to which they felt no sense of belonging, and from whom they enjoyed minimal protection.

Following a renegotiation of the Bougainville Copper Agreement ${ }^{15}$ in 1976 , increased benefits began to flow to Bougainville. Yet increased benefits were not always enough to avoid conflict. Rather than resolving issues, the distribution of increased material resources at times created new tensions among Bougainvilleans. One issue for example, was that compensation payments did not keep up with the rapid population growth in the mine lease areas in the early I970s (Regan, 2007, p. 96). Tensions arose 'between the leaders of younger landowners and the older generation who were in charge of landowner organisations to which some forms of compensation were paid for long-term investment and limited distribution purposes' (Regan, 2007, p.96). Specifically, members from the younger generation believed board members of the Panguna Landowners Association were siphoning off funds for their own benefit. The younger generation of landowners formed their own association, dubbed the New Panguna Landowners Association (NPLA). The NPLA was distinguished by its younger membership but also its 'organised nature, the sophisticated use of arms and explosives, and its persistence' (Wesley-Smith, I99I, p.I88-9). Francis Ona, an employee of BCL, eventually took over as head of the NPLA and demanded an unsustainable ro billion kina for environmental damage plus a 50\% share of the mine revenue (Braithwaite, Charlesworth, Reddy \& Dunn, 2010, p.I9). When denied these demands, Ona called for the mine to be closed and further attacks were made on BCL property. The inter-generational dispute over access to BCL's resources sparked the initial conflict around the mine site.

The divisions and conflict between landowner groups further aggravated the communication problems that marked the interactions between BCL, the national government and landowners. The intersections of resource development with pre-existing cultural, political and economic marginalisation also

15 An analysis of the negotiation of the Bougainville Copper Agreement can be found in Denoon (2000). 
constrained efforts by BCL to build effective stakeholder consultation and an effective partnership with Bougainvilleans.

Conflict escalated in I988 following an attack on an electricity pylon at the mine on orders from Francis Ona. Tensions had also intensified between Bougainvilleans and internal migrants; the PNG Government sent in police riot squads to regain control and to restore mining activities. In the context of existing tensions between Bougainville and PNG, this action resulted in immediate claims of police brutality. The Bougainville Revolutionary Army retaliated with further attacks on government property to which the government responded in June 1989 by inserting the Papua Guinea Defence Force (PNGDF) and declaring a state of emergency on Bougainville (Braithwaite, Charlesworth, Reddy \& Dunn, 2010, p.24).

The entry of the PNG military and subsequent allegations of human rights abuses led to the emergence of an organisation which became known as the Bougainville Revolutionary Army (BRA). Some estimate the group had up to 300 armed and active members in I990 'and undoubtedly enjoyed the assistance of many more’ (Wesley-Smith, I99I, p.I89). However BRA forces were often undisciplined and disorganised (Regan, I998, p.278). Other Bougainvilleans opposed the BRA because they resented the withdrawal of government services that followed the BRA's attacks on government property. These Bougainvilleans formed what became known as the Bougainville Resistance Forces (BRF) in the early I990s, which overtly pitted Bougainvilleans against Bougainvilleans, adding new complexities and dimensions to the conflict ${ }^{16}$.

\section{Social and environmental impacts}

Once production at the mine began, it was the influx of 'outsiders' from other parts of PNG, which became a pervasive issue relating to PNG's governance of Bougainville. At least, this was the main source of hostility for Bougainvilleans not directly affected by the mine. In contrast, the displaced Nasioi held a quite different set of grievances, primarily associated with their loss of land, environmental degradation, and of the standard of housing provided by BCL (Regan, I998, p.276).

It is estimated that more than I0,000 (mostly) men were employed by BCL at the peak of construction (Howley, 2002, p.29). This dropped to approximately 4,000 in the I980s (Regan, I998, p. 275) of which $80 \%$ were estimated to be Papua New Guinean and 30\% to be Bougainvillean (Wesley-Smith \& Ogan, I992, p.257).

However the main source of tension was not the high proportion of nonBougainvilleans employed at the mine, but rather the activities of PNG migrants

16 For a more detailed description of how these events unfolded, see Regan (I998). 
who remained on Bougainville regardless of whether they held employment at the mine as well as the concerns of young Bougainvillean mine workers who shared significant complaints which led to the escalation of violence (Regan, 20I0, p.I8). Thus, while the migrants did indeed take thousands of jobs at the mine (Braithwaite, Charlesworth, Reddy \& Dunn, 2010, p.20), of equal concern to the Bougainvilleans were the unemployed 'squatters' who established bush camps on the outskirts of the mine or gained employment on plantations or in other small businesses. As a Bougainvillean ABG Department CEO stated:

....an influx of people came. Over time people's attitudes changed because they brought social problems. They started creating problems and gave rise to conflicts. They were settling on people's land. [They] acted against our way of living. People took advantage of the situation. Not BCL workers but the people who came for attraction. BCL employees were not the problem, [it was] the people in the bush camps (ABG Department CEO, interview with author, 20I0).

Bougainvilleans resented the PNG migrants' lack of respect of Bougainvillean customs. For example they established gardens and camps on customary land without the prior approval of landowners. The migrants not employed by the mine were also blamed for an increase in a variety of community safety issues including rape, assault, prostitution and alcohol abuse (Connell, I990, p.5I). New social problems associated with mining also manifested through what Filer refers to as the, 'economic stratification of the landowning community' (Filer, I990, p.II6). Newly acquired wealth distorted the traditional social structures of village life because of the status it generated for young 'playboys' that could not be matched by the elder village leaders (Howley, 2002, p.29). As a consequence, Howley (2002, p.30) claims that the young people began to discover a new socialisation process where they increasingly focused on imitating peers rather than aspiring to the cultural values of the elders in the community. The greatest impact of these changes was on the status of women in the community, who had previously played a significant role in social control (Regan, I998, p.275).

Due to the enormous scale of the mine and the environmental damage caused by BCL's tailings disposal system, the Nasioi were not the only landowning group to be affected by the development of the mine. Consequently, the mine affected a significant proportion of the population, and created enormous landowner resentment for removing I.2I5 billion tonnes of their land and turning 99.4\% of it into waste (Dorney, 2000, p.40).

While the original I967 Agreement between the Australian Administration and BCL restricted the dumping of tailings waste, this regulation was eventually reversed to allow tailings to be disposed of in the Kawerong-Jaba river system. This is believed to have caused chemical pollution of the river, killing off fish stocks, an important source of protein for local villagers. The development of the mine and its supporting infrastructure also led to the permanent alienation of agricultural land and traditional food sources. For a population dependent upon agriculture, the loss of this land represented a significant threat to the future survival of Bougainvilleans and their traditions. 
From mid-I997, Bougainville made significant progress towards peacebuilding. Following a number of what appeared to be unsuccessful peace efforts, war weariness and a stalemate provided momentum for 'leadership to heed both sides of the BRA/BRF conflict as well as the PNG government' (Regan, 20I2, p.I23). Assisted by the New Zealand and Australian Governments, negotiations began on a political settlement between Bougainville and PNG which culminated in the 200I Bougainville Peace Agreement. Key components of the Agreement were:

Autonomy for Bougainville within PNG

A referendum on independence for Bougainville deferred for 2 to 15 years after autonomy began to operate

Withdrawal of PNG forces from Bougainville and disposal of weapons held by Bougainville factions

Constitutional entrenchment of the arrangements

- Sequencing of implementation steps to provide incentives to parties to implement what they might otherwise have seen as against their interests ${ }^{17}$ (Regan, 2012, p.I24-5)

In 20I2, Bougainville was formally recognised as an autonomous region of PNG, and has experienced over I5 years of peacebuilding activity. The primary focus of these peacebuilding initiatives has been to open spaces of dialogue between Bougainvillean and PNG leaders, as well as reconciliation between combatants of the BRA and the BRF. Although the peace process has generally been viewed as successful (Turner, 2007, p.93), it did not include important issues relating to resource development, such as a revenue sharing agreement for future mining. This has led some analysts to describe the Bougainville peace process as possibly 'conflict deferred' (Regan, 20I2).

\section{A return to mining?}

From 2007 onwards, support for reopening the Panguna mine began to build among the Bougainville political elite. Renewed interest in mining is attributable to a requirement in the 200 I Bougainville Peace Agreement that a referendum on Bougainville's independence from PNG be held sometime between 2015 and 2020. Many Bougainvilleans believe that neither a meaningful autonomy nor independence will be economically viable without a substantial source of revenue $^{18}$ (Jennings \& Claxton, 20I3, p.7). Thus, the long-held desire among a

17 For a comprehensive account of the Bougainville peace process, see Regan, 20IO, 2 OI2.

18 A recent report published by the Australian Strategic Policy Institute suggests that 'Bougainvilleans do not yet have realistic options to choose either autonomy or independence' (Jennings \& Claxton, p.I). This is attributed to misunderstandings between Port Moresby 
significant proportion of Bougainvilleans for political independence from PNG continues to frame the mining debate on the island. This time around, potential mining revenue is viewed as a means to support Bougainvillean independence from PNG, rather than PNG's independence from Australia.

To gauge local support for the resumption of mining at Panguna, the ABG and the PNG Government agreed that the Bougainville Copper Agreement should be reviewed. As the Agreement has not been reviewed since the I970s, landowners and the Bougainville Government have been left with uncertainty on a number of important issues such as the availability of revenues from Panguna in the future, and the responsibility for stabilising the mine site if it is never to reopen (Bougainville Administration, n.d, p. 6). For these and other outstanding issues to be clarified, the Agreement must be renegotiated.

Reflecting the significant changes that have occurred on Bougainville, the negotiation process will include the $\mathrm{ABG}$ and representatives of landowners. For the first time, the right of Bougainvilleans to be consulted on whether they want mining will be recognised. To ensure the widest representation of landowners is included in the review process, the ABG has embarked on a process of establishing nine separate associations and one umbrella body for customary landowners from BCL's mining-related leases.

According to the Bougainville Administration, the aim of establishing these associations is to recognise that while each mining-affected area has distinct needs and concerns, they also need to develop the capacity to speak with one voice when they begin negotiations on the future of the mine (Bougainville Administration, n.d, p.8). Reflecting the sensitivity of the mine issue and the fact that reconciliation between the 'old' and 'new' Panguna landowners has only very recently occurred, it has taken many months for these landowning groups to agree to work together (Nisira \& Garrett, 20II). Despite this, Regan reports that the process to date has been fruitful:

...the people are very clear, they know what their problems are and they are identifying them with tremendous clarity and great emotion. They really feel they have suffered, they are aware that they are the real victims of mining, and they are not opposing mining, for the future for the most part, but they are saying if it is to happen again, then it is to be done very differently and they, amongst others, have to be looked after in very different ways (Regan \& Garrett, 20II).

Consequently, the emphasis in the literature on business fostering peace through contributing to a sense of community is relevant to the Bougainville case. However, it is the ABG and not BCL that is driving this process. As we will see, this is due to the fact that BCL itself is expected to participate in some

and the ABG, continued divisions among Bougainvilleans as well as new pressures to resume mining (Jennings \& Claxton, 20I3, p.I). Further, there are considerable concerns that instead of consolidating their presence in the lead up to the referendum, PNG is not only under-investing in Bougainville (Oppermann \& McKenna, 2013) but has failed to fulfil all of its funding obligations under the Bougainville Peace Agreement (Jennings \& Claxton, 2013, p.6). 
form of reconciliation before it would be in a position to play a lead role in the reopening of the mine.

The three main options the parties to the review process must consider are: I) the mine never opens again; 2) the mine opens again as a BCL operation; and 3 ) the mine opens again under control of some other company (Bougainville Administration, n.d, p.4). In order to illustrate the potential roles that BCL might play in Bougainville's future, each of these options will be explored in more detail. This discussion will be followed by suggestions on how and why BCL might participate in local reconciliation processes on Bougainville.

\section{Option 1: the mine never opens again}

If the mine re-opens there will be another war. That's what I predict (Bougainvillean landowner, interview with author, 2010).

Despite the emerging consensus among many Bougainvilleans that the mine should reopen, this view is not without dissent. Numerous high profile individuals express concerns that reopening the mine could jeopardise Bougainville's peace process. The main fears are that:

- The Bougainville Government will not have the capacity to contain local interests

There is the potential for warlords to emerge

- Unresolved conflicts might erupt, which have the capacity to turn deadly due to the many weapons that continue to be available on the island (Regan \& Tanis, 20II)

In addition, there are concerns that the resumption of mining will lead to a resurgence of the social and environmental problems that plagued Bougainville during the operating years of the mine. As one Bougainvillean stated: '...we have already seen the damages. There are a lot of fears. Not only about the mine but fear of the PNG military coming back. Even the loss of land' (Me'ekamui spokesman, interview with author, 20I0).

While there are no official groups opposing the mine as such, there are a number of well-known Bougainvilleans opposing the resumption of operations. For example Damien Dameng, a strong complainant of the impacts of the mine on traditional values during the I970s and 8os, has expressed opposition to mining (Taylor \& Garrett, 20II). Those who share Dameng's view believe that instead of reopening the mine, stakeholders of the review should: '...work on the exit strategy and fill that bit [the mine pit] and make it conducive for cultivation' (ABG Department CEO/landowner, interview with author, 20I0).

In addition to Dameng, Chris Uma, leader of the Bougainville rebel group the 'Original Me'ekamui', has expressed reservations about the resumption of mining. Uma's opposition is due to numerous outstanding issues between landowners, BCL and the National and Provincial Governments. Uma states: 
...Bougainville is not yet normal, there are issues we still have to sort out first. Things like compensation, I also want the mine pit measurement looked at and people compensated fairly for the damages done to this hole. We have to address and settle this before we can start talking about mine reopening (cited in Kenneth, 20II).

This quote, and other statements made by Uma on Australian radio programmes (Uma, Tanis \& Garrett, 20II) indicate that Uma does not entirely rule out the resumption of mining on Bougainville. However, he does hold a firm view that the parties to the negotiation process must deal with the unresolved issues of compensation and environmental restoration, before any commitments are made on the future of the mine. Should these issues not be adequately dealt with, the potential for armed conflict is high. In spite of Dameng and Uma's concerns, the numbers of Bougainvilleans in favour of reopening the mine is much larger. Indeed, all three Bougainvillean leaders who have served as President (Kabui, Tanis and Momis) have supported the resumption of largescale mining, either at Panguna or elsewhere.

\section{Option 2: the mine opens again as a BCL operation}

People would prefer to work with the devil they know. They [BCL] will understand what they did wrong (ABG Department CEO, interview with author, 20IO).

While no systematic survey research evidence is available, Regan and Tanis (20II) suggest that approximately 95\% of Bougainvilleans support reopening the mine and my own fieldwork also suggests a high level of support. This support is based on the view that Bougainville requires a reliable source of economic development for an independent future to be feasible. In this regard Chairman and Managing Director of BCL, Peter Taylor, claims that the Panguna mine is potentially:

...large enough to support the Bougainville economy and also to produce a large number of jobs and businesses that always develop around a major project. There are stats [statistics] about how many direct employees will lead to how many indirect employees and the ratio is about 5 to I so if we are employing 3000 people you can expect another I5,000 people to be employed locally (Taylor \& Garrett, 20II).

In addition, the mine is estimated to have a life of approximately $17-20$ years of mineral production remaining and is believed to contain, '3.5 million tonnes of copper, today worth about $\$ 32.4 \mathrm{bn}$, and I2.7 million ounces of gold, worth today about \$I7.8 bn' (Callick, 20IO). In this way Panguna is considered to be a viable option to support an independent Bougainville for at least I5 years. If the Bougainville Government and landowners deem these 15 years of mining a success, there is also the potential for new mining projects to be developed on other parts of the island.

Should Bougainvilleans decide to reopen the mine, fieldwork observations suggest that BCL would likely be the preferred operating company. Many Bougainvilleans the author spoke to explained this preference on the basis that, 'it's better the devil you know', implying that it would be better to work with BCL 
(which wants to return to Bougainville), rather than risk a company that may have lower social and environmental standards. They also believe that BCL will accept some responsibility for what went wrong, something they fear a new company may not. Additionally, there is a popular perception on Bougainville that because BCL was the company which created many of the social and environmental problems that have plagued Bougainville since the I970s, it should also be BCL that comes back to fix these problems. Here the reconciliation and legal arguments converge, as BCL still has a valid legal right to mine. As a Bougainvillean ex-BRA combatant stated: '...they [BCL] can just come back. They can do reconciliation with landowners and start a new chapter. BCL has to come back because it did that [the social and environmental damages] no other company can come back' (interview with author, 20I0).

Underlying this openness to BCL is also a trust that the company has learned from its mistakes, and as a consequence, will be more committed to protecting the rights of landowners and their environment in the future. As two Bougainvillean landowners stated:

I only deal with BCL. They have been here. They did the environmental damage.

I will only talk to BCL. They know me (landowner, interview with author, 20I0).

BCL already learned its mistakes. There will be better things with BCL again (ABG

Department CEO/landowner, interview with author, 20IO).

Within these statements there is also a sense of confidence among Bougainvilleans that they have the capacity to hold BCL socially and environmentally accountable. As one Bougainvillean landowner stated, 'people are willing to sit with BCL to once again remind them what stimulated them to take up arms' (ABG Department CEO/landowner). Alongside the idea of inviting BCL to reopen Panguna therefore, is a strong expectation that the suffering Bougainvilleans have experienced through the previous mining experience will be acknowledged. As such, the future of mining is inextricably tied to the Bougainvilleans' understanding of the past and their aspirations to define the future. However continued support for BCL on Bougainville will profoundly depend on how it handles outstanding issues such as compensation and environmental damage. As the following landowners stated:

You [BCL] must pay out the damages [first] or we can find another company (chief/ landowner, interview with author, 2010).

What we want is compensation for the damage. If they cannot sort out the [existing] problems they cannot come (former BCL employee/ landowner, interview with author, 20IO).

\section{Option 3: the mine opens again under control of some other company}

While numerous companies have been raised as potential alternatives, competition at the corporate level to reopen the Bougainville copper mine is not believed to be fierce. This is due to two main factors. First, BCL holds the legal rights to the mining-lease areas and remaining infrastructure. This means 
that unless Rio Tinto and/or the PNG Government become interested in selling their investment, it is unlikely that another company could obtain a legal right to reopen Panguna (Taylor \& Garrett, 20II). Second, an investment of approximately US \$5.2 billion is required to reopen the mine (Taylor cited in Post Courier 20I3). The ABG believes that there are only four or five companies in the world that have this capacity. Consequently, the companies that have been raised as potential competitors to BCL are believed to only want a slice of equity in the mine, rather than operating status.

Despite these claims, the ABG has reportedly held discussions with several resource companies. For example, an Australian company with links to the China Nonferrous Metals and Mining Company, Ord River Resources, is believed to have held talks with the ABG about reopening Panguna. Ord River heightened public speculation over the future of the mine when it issued several press releases (Ord River Resources 2007a, b, c) stating that talks with the Bougainville Government were 'progressing nicely'. However these talks came to an abrupt end in 2007, when the ABG reportedly ended discussions on the basis that the mine was too sensitive an issue to discuss in the absence of a Bougainville Mining Policy (ABG pulls out, 2007).

Invincible Resources has also been involved in public debate and speculation on Bougainville since the late President of Bougainville, Joseph Kabui, gave the company 70\% control over Bougainville's future mineral resources (Leader denies Bougainville, 2008). The deal was criticised for its lack of transparency, following the revelation that the ABG received $\mathrm{K} 20,000$ (AU\$8000) for 'capacity building' (The Devui Committee, 2008, p.5). The fund was allegedly used by some members of the ABG for their own purposes (The Killer Deal, 2008). Many Bougainvilleans were also angry with the deal as it was made during a period in which it had been made, 'clear that they were not prepared to return to foreigners mining their land' (Rabasca, 2009).

Despite these concerns, there was enough support within the Bougainville Government to oust members of the Bougainville Executive Council who were acting in favour of Ord River.

Following Kabui's death in 2008, there has been a succession of two Presidents of Bougainville with different approaches to the mine issue. According to Braithwaite, Charlesworth, Reddy and Dunn (2010, p.I29), for example, James Tanis, 'has been genuinely open to listening to the diverse and conflicting positions of his people in a new bottom-up attempt to forge a consensus on the future of the mine'. Tanis' logic is that for the Bougainville peace process to be sustainable, the conflict must be taken back to where it started. This links to the earlier discussion about why many Bougainvilleans prefer BCL to other companies. As the current Vice President of Bougainville, Patrick Nisira (Nisira \& Garrett, 20II) claims: ' ... because of Panguna, Bougainville went down the drain and we believe that if we can fix Panguna, if we can stabilise Panguna, we can help Bougainville [stand] on its [own] two feet again'.

While there are hopes on Bougainville that the current President and former PNG Ambassador to China, John Momis, will continue the progress made on 
the mine issue by Tanis, some fear his close links to China will lead him to prefer Chinese investors regardless of the support of landowners. However others argue that while he is not opposed to Chinese investment in Panguna, it is something beyond his influence. As discussed earlier, this is due to the fact that BCL holds the legal rights to the Panguna mine. Therefore, investor partners in a reopened Panguna mine would be determined by BCL.

The huge investment required to reopen Panguna, coupled with the tension surrounding local dealings with Invincible Resources, has meant that it is less likely, though not impossible, that the mine will reopen under a new company. While BCL is clearly attempting to capitalise on the negative experience of the failed Invincible and Ord River deal, Taylor's reflection on the competition facing BCL does seem to ring true, '...having seen the alternatives, the Bougainvilleans are saying, they actually prefer Bougainville Copper to reopen the mine' (Taylor, \& Garrett 20II).

\section{Distributive vs. symbolic reparation}

Given the strong support that currently exists for BCL to reopen Panguna, the idea of a role for BCL in peacebuilding processes is a possibility worth pursuing. From BCL's perspective nothing is off the agenda for talks about reopening the mine, with Peter Taylor encouraging landowners to set the agenda for negotiations themselves (Taylor \& Garrett, 20II). Bougainville therefore, represents a unique opportunity to explore the local expectations of a company involved in prior violent conflict in return for a new social licence to operate.

The Bougainville data suggest there is an expectation for BCL to make both distributive and symbolic reparations for the injustices that have been experienced. As discussed earlier for example, there is a strong 'distributive' expectation for BCL to resolve the outstanding issue of compensation. This reportedly includes Francis Ona's i988 demand of Kio billion for environmental damages. However as, 'the Kina has since depreciated to a third of the US dollar in value, and because metal prices have risen' (Miriori, 2010), this figure is now being demanded in US dollars. Nonetheless, this demand may not be as unrealistically inflated as it was at I980 metals prices due to the significant increase in world copper and gold prices, and the estimated stream of \$50.2 billion in sales remaining in Panguna.

Despite the firmness with which compensation is being demanded, there is also awareness on Bougainville of the social problems that monetary compensation has caused in the past, such as intergenerational disputes. Some Bougainvilleans are suggesting that an apology and/or reconciliation with BCL should also take place. As one Bougainvillean peacemaker stated: 'They [the landowners] will want the company to apologise... The company could participate in peacebuilding by the executives participating in a reconciliation ceremony. Compensation can be paid later' (peacemaker, interview with author, 2010). 
This statement implies that Bougainvilleans are hoping for a compensation deal negotiated from a foundation of reconciliation. If another company were to reopen the mine, the expectations would likely be different. An apology on behalf of the company for past harms for example, would not be required. This is not to say, however, that the company would not need to engage with the association of the mine with conflict. In such a scenario, the company might adopt other strategies which demonstrate an awareness of past grievances and how they might be avoided in the future. The point is that in either scenario, the company may need to consider measures that engage meaningfully with the past ${ }^{19,20}$. Without such engagement, it is conceivable that a new or reopened resource project may provoke resentment in unpredicted ways. The following section explains how BCL's participation in reconciliation could take place.

\section{Reconciliation with $\mathrm{BCL}$}

According to Boege and Franks (20II, p.36-37), if BCL were to participate in customary peacebuilding processes on Bougainville, the company would, 'essentially have to behave as if it were another "clan"'. This would require BCL to make material reparations for the harms caused (e.g. compensation), as well as take practical steps to remedy those harms. The key here is to acknowledge the suffering of those who have been affected and to seek their forgiveness. To do this, current and former BCL executives will be required to put aside their own cultural interpretations of justice and prioritise, 'local ways of doing things' (Boege \& Franks, 20II, p.38).

According to one Nasioi man, Bougainville's justice system is particularly difficult for foreigners to understand as it emphasises forgiveness over punishment (Mekea, cited in Howley, 2002, p.IO2). Bougainvilleans do not consider legal revenge and punishment a necessary part of justice (Howley, 2002, p. I03). As Mekea claims:

...in its simplest form, it [Bougainvillean reconciliation] is just a question of two people saying 'I did you wrong and you did me wrong. I forgive you and you forgive me'. That is what happens in its most simple form. Of course there will be an exchange of goods, money, pigs and shell-money. People in other cultures do not really understand this. They prefer punishment and putting people in jail (Mekea, cited in Howley, p.IO2).

19 In other post-conflict contexts, or where conflict is still ongoing, this might include for example, the implementation of a new security strategy. A new approach to corporate security could be used to limit the presence of the state's security forces in areas where there has been a history of human rights violations surrounding large natural resource projects.

20 See for example, BP's attempt to implement an 'Integrated Community Based Security' approach in West Papua. The aim of this model has been to limit the presence of Indonesian security forces in the area surrounding the Tangguh Liquified Natural Gas Project (BP p.1.c. 20I3). 
It is likely that BCL executives will want to avoid participation in this type of reconciliation, particularly through fear of admissions that might be used in litigation. However even allowing for these risks, engagement in local reconciliation could be a win-win scenario for both BCL and landowners. For example, there is evidence in the regulatory literature that suggests where symbolic reparation is made (e.g. an apology), victims are less likely to seek redress through judicial mechanisms (Healy, 20II, p.269). Local reconciliation could thus be an attractive option for BCL whose parent company, Rio Tinto, has been caught in a lengthy lawsuit in the United States ${ }^{21}$. In return for a suite of reparative and reconciliatory measures (which could include investment of the resources that would otherwise go to fighting a legal case into community development projects), BCL could ask for all the leaders of Bougainville to commit not to take legal action.

The US lawsuit mentioned above involves serious allegations against Rio Tinto that should not be dismissed lightly. However there are concerns as to how representative the case is and the benefits that can be derived from a court battle in the United States. By participating in a process that holds meaning for locals, BCL could be in a better position to be, 'truthful with the people on what happened in the past' (Bougainvillean small-scale miner, interview with author, 20I0) and apologise for the social and environmental damage that mining brought to the island. If landowners then invited BCL to reopen Panguna, it would send a strong message to both current and future shareholders that Bougainville copper represents a secure investment. Importantly therefore, both BCL and landowners have an interest in exploring alternative redress mechanisms that draw upon local reconciliation processes.

My fieldwork observations suggest Bougainvilleans consider an apology a small ask of the company, but a significant test for how culturally sensitive BCL would be if it were to reopen Panguna. As the following Bougainvillean women's leaders stated:

...cultural/symbolic recognition-it's our way of thinking. It is good manners. If they [BCL] were culturally sensitive, it would come naturally (former BCL employee/ women's leader, interview with author, 20I0).

...It can be small but people will appreciate it. They should speak and say sorry about the damages. The people will speak about the loved ones and they will invite the spirits to invite them back (women's leader, interview with author, 20I0).

Regarding how reconciliation between Bougainvilleans and BCL could take place, it is best to think of reconciliation as an on-going process that involves 'shallow and weak' forms of restoration. For example, 'shallow reconciliation' between Bougainville and BCL has already started by way of invitations to Peter

21 Allegations against Rio Tinto were recently dismissed by the United States Court of Appeal due to the limited reach of the Federal Alien Tort claims Act to cases not involving the US. Following the Kiobel v. Royal Dutch Petroleum Co case, the judges in that case defined the Statute as designed to cover only breaches in the US rather than abroad. 
Taylor as Chairman of BCL to visit Bougainville for the first time since the closure of the mine. In addition, a delegation of senior Australian diplomats was allowed to see the mine site for the first time in two decades (Taylor \& Garrett, 20II). For 'deep reconciliation' to occur, there is an expectation that current and former BCL executives should go to Bougainville to participate in, 'a meeting, and then a ceremony' (Bougainvillean ex-combatant, interview with author, 20I0).

Traditionally, Bougainvillean peace ceremonies involve a feast during which 'former adversaries may feast, drink, and dance together; chew betel nut together; and symbolically break spears and arrows' (Boege and Franks, 20II, p.38). While Bougainvilleans recognise that, 'injustice is deep and it will not heal overnight' (Bougainvillean women's leader, interview with author, 20I0), there remains a strong faith in the customary reconciliation process to restore relationships and to, 'heal the pain' (Bougainvillean women's leader, interview with author, 20IO). There is a strong sense of confidence that if BCL were to engage in the 'Bougainville way' of reconciliation, there would be a strong foundation for a new working relationship.

\section{Prospects and obstacles}

While a reconciliation ceremony between BCL and Bougainvilleans is now under active consideration (planned for early 20I4), there are no guarantees that this kind of acknowledgement of previous errors will result in a more considered approach in the future. Even if BCL were invited back to Bougainville and were willing to make reparations for the past, future harmful practices, intentional or otherwise will always be a risk.

Negotiations on the potential for BCL to return to Bougainville are also occurring at a time when it is unclear who the ultimate governing authority will be after the referendum on independence. To add further uncertainty, the outcome of the referendum will be subject to ratification by the PNG Parliament (Jennings \& Claxton. 2013, p.5). Some fear the potential for future bloodshed if the PNG Parliament votes down Bougainvillean independence (Jennings \& Claxton. 20I3, p.5). In this context, BCL would once again be required to straddle two governing authorities with divergent interests.

It is not necessarily certain however, that PNG's refusal to ratify a vote for independence would reignite conflict (Jennings \& Claxton, 20I2, p.6-7). Nor is it certain that an influx of money into Bougainville would spark envy from the rest of PNG. This is due, in part, to a lack of capacity and appetite for renewed hostilities and the fact that PNG is no longer economically dependent on Bougainville's natural resources (Jennings \& Claxton, 20I2, p.8). There are many possibilities that could unfold on Bougainville as it approaches the 20I5-20 referendum on independence. This paper has merely explored some of the potential peacebuilding opportunities which BCL might explore if it were invited to return to Bougainville. 


\section{Conclusion}

A detailed analysis of the roles that corporations have played in specific armed conflicts is the first step to implementing a conflict-sensitive business strategy. Through a discussion of the contemporary scenario of resource development on Bougainville, it has been argued that BCL is faced with important opportunities to participate in facilitating peace, especially through local reconciliation processes. These processes extend beyond the spillovers of economic development. They include very precise expectations for both distributive and symbolic reparations for the company's entanglement in the Bougainville conflict. While BCL cannot be expected to take responsibility for the entirety of the conflict, it is expected that it will need to engage with the ways in which it contributed to it. Core issues include recognition of how its revenues provided the financial means for Bougainville's entrapment into a political relationship with PNG. Overcoming or reconciling this fact will require more than economic development, jobs, and 'a sense of community'. In order to return to Bougainville, BCL will be required to reconcile with Bougainvilleans on the consequences of this political marriage, such as clear statements on how it will deal with future security threats and the PNGDF, as well an influx of migrants from other parts of PNG. This is something which will be arguably easier for BCL to handle if it were to reopen Panguna in the context of an independent Bougainville. If, however, the mine were to reopen in the context of continued autonomy arrangements within PNG, these issues will be extremely volatile and will require a strong commitment on the part of the PNG Government to complement efforts to establish a peaceful resource project.

By drawing on a case study of a corporation that was perceived to be directly related to resource conflict, this article has pointed out a number of avenues through which business can contribute to peace that do not currently exist in the literature. Moreover, it has argued that corporations that are wishing to contribute to peace via the overlap between economic development and peace may need to participate in local reconciliation processes before they can adopt this role. This finding has important implications for future research on business and peace. In order to ensure the relevance of this scholarship to the extractive sector, there is a need to identify peacebuilding roles for an industry whose activities are often a key factor in the escalation of violence. This paper has suggested one avenue through which these possibilities can be explored: through a stronger focus on conflicts where business activity has been a source of prior conflict. Due to the number of countries currently experiencing the post-Cold War boom in conflict settlements, a focus on businesses returning to resume their activities in post-conflict situations is both timely and necessary. 


\section{References}

ABG pulls out of Panguna mine talks. (2007). Post-Courier Online. I2 March 2007. Retrieved from www.postcourier.com.pg/20070312/newso3.htm

Andersson, J.J., Evers, T., \& Sjostedt, G. (20II). Private sector actors Q peacebuilding: A framework for analysis. The Swedish Institute of International Affairs. Available online www.ui.se/upl/files/66320.pdf

Bais, K. \& Huijser, M. (2005). The profit of peace: Corporate responsibility in conflict regions. Greenleaf Publishing: Sheffield.

Banfield, J., Haufler, V., Lilly, D. (2005). Transnational corporations in conflict prone zones: Public policy responses and a framework for action. International Alert: London.

Boege, V. \& Franks, D.M. (2OII). Re-opening and developing mines in post-conflict settings: the challenges of company-community relations. In P. Lujala \& S. A. Rustad (Eds.), High-value natural resources and post-conflict peacebuilding. Series in Peacebuilding and Natural Resources, Vol. I. Earthscan: London.

Bougainville Administration. (n.d). Awareness materials: Establishing representative structures for landowners of BCL mining-related leases. Unpublished document.

BP p.l.c. (20I3). 'Tangguh Integrated Community Based Security'. Retrieved from www.bp.com/sectiongenericarticle.do?categoryId=900477I\&contentId=7009I47

Braithwaite, J., Charlesworth, H., Reddy, P. \& Dunn, L. (2010). Reconciliation and architectures of commitment: Sequencing peace in Bougainville. ANU E Press: Canberra.

Callick, R. (20II). 'Battle Intensifies over Bougainville Copper'. The Weekend Australian, I6-I7 July, 20 II, p.6.

Collaborative Engagement Project. (2003). The role of business in conflict resolution and peace building. Retrieved April, 22, 2012, from www.inec.usip.org/resource/rolebusiness-conflict-resolution-and-peace-building

Connell, J. (I990). 'The Panguna mine impact (I)'. In Polomka, P. (Ed.), Bougainville: Perspectives on a crisis. Strategic and Defence Studies Centre, Australian National University: Canberra. pp.43-48.

Denoon, D. (2000). Getting under the skin: The Bougainville Copper Agreement and the creation of the Panguna mine. Melbourne University Press: Carlton South.

Dorney, S. (2000). Papua New Guinea: People, politics and history since 1975. Random House: Milsons Point, NSW.

Filer, C. (I990). 'The Bougainville rebellion, the mining industry and the process of social disintegration in Papua New Guinea'. In May, R.J. \& Spriggs, M. (Eds.), The Bougainville crisis (pp.73-II2). Bathurst: Crawford House Press.

Filer, C., Henton, D. \& Jackson, R. (2000). Landowner compensation in Papua New Guinea's mining and petroleum sectors. Papua New Guinea Chamber of Mines and Petroleum: Port Moresby.

Ford, J. \& McKenna, K. (2008). 'Peacebuilding and the private sector: Scoping a research agenda'. Centre for International Governance and Justice, Issues Paper 4.

Fort, T.L. \& Schipani, C.A. (2004). The role of business in fostering peaceful societies. Cambridge University Press: Cambridge.

Fort, T.L. (2007). Business, Integrity, and Peace. Cambridge University Press: Cambridge.

Gerson, A. (200I). 'Peace building: The private sector's role'. The American Journal of International Law, 95(I), I02-II9.

Giroux, J., Burgherr, P., \& Melkunaite, L. (2013). 'Research Note on the Energy Infrastructure Attack Database'. Perspectives on Terrorism, $7(6)$, II3-I25.

Griffin, H.M. \& Regan, A.J. (2005). Introduction. In Regan, A.J. \& Griffin, H.M. (Eds.), Bougainville before the conflict. Pandanus Books: Canberra. pp.xxvii-xxxvii. 
Healy, J. (20II). Improving health care safety and quality: Reluctant regulators. Ashgate: Farnham.

Howitt R. (2002). Rethinking resource management: justice, sustainability and indigenous peoples. Routledge: London.

Howley, P. (2002). Breaking spears and mending hearts: Peacemakers and restorative justice in Bougainville. Zed Books: Annandale.

Jennings, P. \& Claxton, K. (20I3). 'A stitch in time: Preserving peace on Bougainville'. Australian Strategic Policy Institute, Special Report. Retrieved from https://www.aspi .org.au/publications/special-report-a-stitch-in-time-preserving-peace-on-bougainville/ SR59_bougainville.pdf

Kaldor, M. (2007). New Q old wars: Organized violence in a global era (2nd edn). Cambridge: Polity.

Kenneth, G. (20II, February 28). 'Rebel hits out against mine talks'. Post-Courier. Retrieved from www.minesandcommunities.org/article.php? $\mathrm{a}=10756$

Laukai, A. (20I3, March 7). 'President blames Australia and Rio Tinto for Bougainville war'. New Dawn. Retrieved from www.ramumine.wordpress.com/2013/03/07/presidentblames-australia-and-rio-tinto-for-bougainville-war

McKenna, K. (2012). Interdependent Engagement: Corporate Social Responsibility in Bougainville and Papua. Doctoral Dissertation: Australian National University.

Miriori, P. (2010, March 26). 'Media Release'. Unpublished document.

Nash, J., \& Ogan, E. (I990). 'The red and the black: Bougainvillean perceptions of other Papua New Guineans'. Pacific Studies, I3(2), I-I7.

Nattrass N. (1999). 'The Truth and Reconciliation Commission on business and apartheid: a critical evaluation'. African Affairs 98(392), 373-391.

Nisira, P. (Speaker) \& Garrett, J. (Presenter). (2OII, March 3I). Bougainville consultations on mine re-opening set to widen [Podcast radio programme]. Sydney: ABC Radio Australia. Retrieved from www.radioaustralia.net.au/pacbeat/stories/20II03/s3I78057.htm

Oetzel, J., Westermann-Behaylo, M., Koerber, C., Fort, T. L., \& Rivera, J. (2009). 'Business and peace: Sketching the terrain'. Journal of business ethics, 89(4), 35I-373.

Ogan, E. (2004). 'Bougainville, personal and professional'. In Lal, B.V. (Ed.), Pacific places, Pacific histories: essays in honor of Robert C. Kiste. University of Hawai'i: Honolulu. pp.I20-I34.

Oppermann, T. \& McKenna, K. (2013). 'Sustainability of Bougainville'. State, Society Q Governance in Melanesia In Brief, no. 7. Retrieved from www.ips.cap.anu.edu.au/sites/ default/files/SSGM\%20IB\%2020I3-7.pdf

Ord River. (2007a). Update on Bougainville. Retrieved from www.ord.com.au/wp-content/ uploads/announcements/2007/Update\%200n\%20Bougainville.pdf

Ord River. (2007b). Update on previous report in media on Bougainville. Retrieved from www.ord.com.au/wp-content/uploads/announcements/2007/Update\%20on\%20 Prevous\%2oReport\%2oin\%2oMedia\%2oon\%2oBougainville.pdf

Ord River. (2007c). Report in Media on Bougainville. Retrieved from www.ord.com.au/wpcontent/uploads/announcements/2007/Announcement\%20Report\%20in\%20 Media\%2oon\%2oBougainville.pdf

Post Courier (2013, April 9). Bougainville Copper Limited set to re-open Panguna mine. Retrieved from: www.islandsbusiness.com/news/papua-new-guinea/82I/bougainvillecopper-limited-set-to-re-open-panguna

Quodling, P. (I99I). Bougainville—the mine and the people. Centre for Independent Studies: St Leonards.

Rabasca, A. (2009). ‘The riches of Bougainville'. Within Reach, 7(2).

Regan, A. (I998). 'Causes and course of the Bougainville conflict'. Journal of Pacific History, $33(3), 269-285$. 
Regan, A. (2007). 'Development and conflict: The struggle over self-determination in Bougainville'. In Brown, M.A (Ed), Security and development in the Pacific Islands: Social resilience in emerging states. Lynne Rienner: Boulder \& London.

Regan, A.J. (2010). Light Intervention: Lessons from Bougainville. US Institute of Peace Press: Washington.

Regan, A.J. (20I2). 'Bougainville: Conflict deferred?' In Aspinall, E., Jeffrey, R. \& Regan, A.J. (Eds), Diminishing conflicts in Asia and the Pacific: Why some subside and others don't. Routledge, Oxon. pp. II9-г36.

Regan, A.J. \& Tanis, J. (2010, November). Neweconomic interests and the future of peace-building in Bougainville. Paper presented for the State, Society and Governance in Melanesia and Resource Management in Asia-Pacific, The Australian National University, Canberra.

Regan, A.J. (Speaker) \& Garret, J. (Presenter). (20II, August 4). Villagers relocated by Bougainville copper suffer most says peace advisor [Podcast radio programme]. Sydney: ABC Radio Australia. Retrieved from www.radioaustralia.net.au/pacbeat/stories/20IIo8/ s3285078.htm

Rettberg, A. (2007). 'The private sector and peace in El Salvador, Guatemala, and Colombia'. Journal of Latin American Studies, 39, 463-494.

Ross, M. (2004). 'How do natural resources influence civil war? Evidence from thirteen cases'. International Organization, 58(I), 35-67.

Santa Barbara, J., Dubee, F., \& Galtung, J. (2009). Peace Business: People and Nature above Markets and Capital. Transcend University Press: Basel/Switzerland.

Shankleman, J. (2006). Oil, profits and peace: Does business have a role in peacemaking? US Institute of Peace Press: Washington.

Sherman, J. (200I). 'Private sector actors in zones of conflict: Research challenges and policy responses'. International Peace Academy Workshop Report, Retrieved from www.ipinst.org/media/pdf/publications/pdf_report_private_sector.pdf

Sherman, J. (2002). Options for promoting corporate responsibility in conflict zones: Perspectives from the private sector. International Peace Academy: New York.

Sirivi, J.T., \& Havini, M.T. (Eds.) (2004). As mothers of the land: The birth of the Bougainville women for peace and freedom. Pandanus Books: Canberra.

Taylor, P. (Speaker) \& Garret, J. (Presenter). (20II, February I7). Bougainville's Panguna mine 'can be reopened' [Podcast radio programme]. Sydney: ABC Radio Australia. Retrieved from: www.radioaustralia.net.au/asiapac/stories/201102/s3141923.htm

Thompson, H. (I99I). 'The economic causes of the Bougainville crisis'. Resources Policy, March I99I, 69-84.

The Devui Committee. (2008). 'Report on the BRDC Inquiry'. Retrieved from www.cdi.anu .edu.au/.AP/2009-IO/D/20IO_OI_BGV_Comm_rep/20IO_OI_BRDC.pdf

The Killer Deal. (2008, June I7). Foreign Correspondent, ABC News. Retrieved from www.abc.net.au/foreign/content/oldcontent/s24648I2.htm

Turner, M. (2007). 'Autonomous regions and the contribution of international relations to peace and development: Mindanao, Bougainville and Aceh'. Ethnopolitics, 6(I), 89-103.

Uma, C., Tanis, J., (Speakers) \& Garrett, J. (Presenter). (20II, August Io). Rebel leader wants to talk about reopening Bougainville copper mine [Podcast radio programme]. Sydney: ABC Radio Australia. Retrieved from www.radioaustralia.net.au/international/radio/ onairhighlights/rebel-leader-wants-to-talk-about-reopening-bougainville-copper-mine

UNEP. (2009). From conflict to peacebuilding: The Role of Natural Resources and the Environment. United Nations Environment Programme. Retrieved from: www.postconflict.unep .ch/publications/pcdmb_policy_or.pdf

United Nations Global Compact. (2010). Doing business while advancing peace and development. Retrieved January I2, 20II, from www.unglobalcompact.org/docs/issues_doc/ Peace_and_Business/DBWAPD_2oro.pdf 
Vernon, D. (2005). 'The Panguna mine'. Regan, A.J. \& Griffin, H.M. (Eds.), Bougainville before the conflict. Pandanus Books: Canberra. pp.258-273.

Wenger, A. \& Mockli, D. (2003). Conflict prevention: The untapped potential of the business sector. Lynne Rienner: London.

Wesley-Smith, T. (I99I). 'Papua New Guinea in I990: A year of crisis'. Asian Survey, 3I(2), I88-I95.

Wesley-Smith, T. \& Ogan, E. (I992). 'Copper, Class, and Crisis: Changing Relations of Production in Bougainville'. The Contemporary Pacific, 4(2), 245-67.

Zandvliet, L. (2005). 'Opportunities for synergy: conflict transformation and the corporate agenda'. Berghof Research Center for Constructive Conflict Management, February 2005. Available online www.berghof-handbook.net/documents/publications/zandvliet_ handbook.pdf 